\title{
Using frames to determine ordinary meaning in court cases: the case of "plant" and "vermin"
}

\author{
Terrence R Carney \\ Department of Afrikaans and Theory of Literature, Unisa, South Africa \\ E-mail: carnetr@unisa.ac.za
}

\begin{abstract}
The South African judicial system has a variety of ways to determine the ordinary meaning of words, ranging from preceding court cases and academic publications to expert witnesses. However, one of the main resources in the interpretation of ordinary words is a dictionary. Much has already been published on both the use (and abuse) of dictionaries in court cases and the ordinary meaning of words as a legal phenomenon. In continuation of this discourse, I propose that jurists consider using a conceptual approach to the interpretation of ordinary words as opposed to relying overly on dictionaries. One such conceptual approach is the use of frames, which deals with meaning in a way that is similar to Gestalt. In this article, I suggest the use of Barsalou's (1992) frame structure that may be applied to a contested word in six steps. To illustrate the way Barsalou's frame functions, I have applied it to two contested words taken from South African court cases. Building a frame in order to determine the ordinary meaning of certain words in court cases proves to be a possible alternative or an additional resource to dictionaries.
\end{abstract}

Keywords: concept, frame, language and law, ordinary meaning of words, prototypes

\section{Introduction}

On 14 January 2011 a man was arrested at his home for possession of dagga. When the police saw that the man also cultivated dagga in his backyard, he was simultaneously charged for dealing in drugs. The respondent in $S v$ Mbatha pleaded guilty on the first charge of possession, but denied that he had dealt in drugs. He claimed that he had cultivated the dagga for personal use and had never intended to sell any of it. However, the respondent was reminded that the words "deal in" were given an extended definition in the Drugs and Drug Trafficking Act, which included the following concepts:

... the transhipment, importation, cultivation, collection, manufacture, supply, prescription, administration, sale, transmission or exportation of the drug ... 
In other words, cultivating is the same as transacting, whether one planned on selling any of one's stock or not. The legislator regularly gives words an extended meaning to reach certain goals, such as restricting drug trafficking or child pornography. In order to prevent child pornography, the Films and Publications Act extends the definition of "child pornography" to the following:

... any image, however created, or any description of a person, real or simulated, who is or who is depicted, made to appear, look like, represented or described as being under the age of 18 years-

(i) engaged in sexual conduct;

(ii) participating in, or assisting another person to participate in, sexual conduct; or

(iii) showing or describing the body, or parts of the body, of such a person in a manner or in circumstances which, within context, amounts to sexual exploitation, or in such a manner that it is capable of being used for the purposes of sexual exploitation ...

Compare this definition to the more straightforward definition of "pornography" in, for example, the South African Concise Oxford Dictionary (Dictionary Unit for SAE 2010: 918): "printed or visual material intended to stimulate sexual excitement". Each Act contains a list of words and phrases that are defined according to the needs of the specific Act. Yet, sometimes the legislator defines words in a particular way without considering their ambiguous nature. Occasionally, the legislator leaves many (problematic) words undefined and, at times, Joe Soap interprets the legislator's words very differently from parliament's intended meaning. When the wording in legislation is unclear, people start fighting over words. Many court cases revolve around the meaning of words and time and again it becomes a court of law's responsibility to explain what words mean.

When words are not defined by the relevant Act or if their legislative definitions are dubious, they should be given their ordinary meanings. This approach was initially determined by the textualist theory of interpretation (and later also the Interpretation Act), which stated that meaning should always be assigned to the wording of a text (Hutton 2009: 71; Du Plessis 2002: 93; Devenish 1996: 26; Du Plessis 1986: 103; Steyn 1986: 4-5; Cockram 1983: 48). This became the golden rule after Judge Innes's ruling (Venter $v R$ ) set the standard in 1907 by stating that clear and unambiguous words should be given their "ordinary effect"(p. 913). Though legal scholars do not always agree on what constitutes the "ordinary meaning" of words, it is usually seen as clear, plain, literal and everyday language (Hutton 2009: 85; Labuschagne 1998: 145), understandable language (Smith 2007: 64; Botha 1998: 6), language that is free of ambiguity, and the popular meaning (Du Plessis 2002: 199; Kellaway 1995: 69). Steyn (1986: 5) refers to the ordinary meaning of words as the language of the sovereign state's subjects, in other words, the language of the common or reasonable man. Of course, the phenomenon of ordinary meaning is not without its problems and fair share of criticism (Carney and Bergh 2014: 3133). What exactly does "ordinary" mean in a legal context and where does the vague and ambiguous nature of words leave one?

\footnotetext{
${ }^{1}$ It is important to note that the "ordinary meaning of words" is a legal phenomenon. The idea of an "ordinary word" might be contentious within linguistics, seeing as words are in famously ambiguous and vague, but within the discipline of law it is mostly used to differentiate between terminology or jargon and non-technical, everyday words.
} 
The South African judicial tradition provides for a number of ways in which the ordinary meanings of words are determined; namely referring to pervious court cases that may have dealt with the same or similar word problems in the past, referring to scholarly publications in mostly the disciplines of law and criminology and, ultimately, referring to a word's definition in a dictionary. Linguistic expertise may be sought for thorny semantic issues, but is not permissible for so-called ordinary words (Du Plessis 2002: 201; De Ville 2000: 99; Hutton 2009: 86; also see $S v$ Allied Steel, Association of Amusement and Novelty Machine Operators $v$ Minister of Justice and Metro Transport v National Transport Commission).

Though this approach to ordinary meaning serves the South African judicial system well, it is not without its flaws. Older cases (for example, $S$ v Makunga and CSARS v Labat Africa) do not always shed more light on semantic issues, leaving a court in the dark. Sometimes presiding officers refer to previous cases with no regard for the nuanced differences in contextual meaning. In Herselman v Geleba, Judge Dawood refers to cases involving the word "baboon" as a derogatory term, without considering the ways in which the word in question differs semantically and pragmatically in each case. Apart from citing previous cases, the use of dictionaries is by far the most important tool to define ordinary words (Labuschagne 1988: 39; Busse 1989: 96-97; Solan 1993: 50; Botha 1998: 103; Labuschagne 1998: 146-147; Kloosterhuis 2007: 262; Hutton 2009: 86-87, and Christensen and Kübbeler 2011: 1, 3-5). Dictionaries are not perfect and though they could be used as a helpful starting point, jurists should be aware of their limitations: they cover a limited scope, they get outdated quickly, they sometimes contain circular definitions, they are acontextual and they are created for different target audiences, of which a South African court might not form part (Carney and Bergh 2014: 41-46).

One of the more important limitations of many dictionaries is the tendency to organise lemmas according to the alphabet. Gouws (1991: 382) refers to an alphabetical organising style as an extralinguistic approach to organisation, which, from a semantic point of view, makes little sense. When lemmas are placed alphabetically, they are taken out of their semantic field and isolated from the many lexical items they are related to. This often leads to word searches ending in restricted definitions of the specific words - that is to say, a lot of the meaning is lost. Instead of focusing on the broader meaning and then moving towards the more refined lexical item, traditional dictionaries start with a word and then provide a possible meaning (Gouws 1991: 383).

This brings me to the purpose and layout of the present article: instead of criticising a court's use of dictionaries or the concept of ordinary meaning, I recommend a way in which courts can determine the ordinary meanings of words with, or without, the aid of a dictionary. By approaching ordinary meaning from a conceptual perspective, that of frames, jurists may get closer to the actual meaning of words, as opposed to their restricted and decontextualised definition. In the next section, I will give a brief overview of concepts, categorisation and frames. This is followed by an introduction of Barsalou's (1992) frame structure and my proposed six steps to describe a word's meaning. In order to illustrate this frame structure, the six steps are then applied to two words taken from South African court cases. 


\section{A conceptual approach}

Cognitive Linguistics lie at the core of a conceptual approach. By studying concepts, Cognitive Linguists explore the relation between language structures and phenomena outside language. This is often achieved by scrutinising language with regard to, inter alia, metaphor, memory and categorisation. In this section, I elaborate on categorisation and frames. However, before I continue, I need to explain briefly what a concept entails within this approach.

According to Langacker (1987: 155-156), semantic meaning can never be autonomous. He argues that a dictionary definition is inadequate to fully define a word. Langacker (1987: 156) sees the interpretation of meaning as inextricably connected to knowledge and cognition; for him it remains a case of conceptualisation. Concepts are the mental images and representations of our knowledge of the world (Löbner 2003: 24). Lyons (1978: 110) describes a concept as an idea, a thought or a mental construct through which the mind gets to know things. Barsalou (1992: 31) sees concepts as "the descriptive information that people represent cognitively for a category", and Margolis (2000: 552-553) views concepts as similar to a filing cabinet. Each file contains different pieces of information, all of it relevant to the file, and each file has a name card that represents all of the information lexically. Furthermore, Margolis (2000: 549, 552-553) points out that concepts stand in relation to the outside world, just as a speaker's knowledge and use of language is connected to the world he/she lives in. Concepts are connected to culture and context, as well as a speaker's understanding of his/her own world and culture. Though individuals have different experiences and therefore different conceptual perspectives, many concepts are also shaped by convention, which means that people's concepts will not necessarily differ that much (especially if people share the same cultural or national identity) (Margolis 2000: 554; Wittgenstein 2000: 174).

Rey (2000: 282-284) lists four main functions of concepts, of which the last three stand out: linguistic function, metaphysical function and epistemological function. Concepts create a platform through which we understand the metaphysical (what the world is comprised of) and the epistemological (what we think or know about the world). These concepts of the world we live in are then communicated through lexicalisation. However, concepts are not represented by a single lexical item only - they are represented by a number of examples or characteristics associated with a concept (Smith and Medin 2000). Furthermore, speakers process information by categorising the different items that belong to a concept. Categorisation is a natural way for people to construct and understand meaning (Rosch 2000: 190; Taylor 2011: 3).

\subsection{Categorisation}

In a series of experiments spanning the 1970s, Eleanor Rosch and others determined that people not only process information by categorisation, but also structure these categories according to best and worst examples. The best example of a category is called a prototype. Rosch (2000: 200) prefers that prototypes be viewed as degrees of prototypicality. A category does not necessarily consist of one single prototype, but may have a few members that are better exemplars than others (also see Rosch 1973). Prototypicality is furthermore formed by family resemblance (by way of attribute overlap). The more attributes members have in common, the more likely they are to be prototypical (Rosch and Mervis 1975). 
In one of her more well-known experiments, subjects were asked to categorise items in natural categories ranging from furniture to carpenter's tools (Rosch 1975). The results for furniture proved "chair" and "telephone" to be the best and worst examples of furniture, respectively. In addition to Rosch, see Mangasser-Wahl (2000), Löbner (2003), Taylor (2009) and Geeraerts (2010) for more in-depth discussions of these experiments. Category members that had the most attributes in common with the prototype (mostly through family resemblances) are also considered to be the most representative and typical members of that category (Rosch and Mervis 1975: 582, 589, 596). Of the 60 items on the list for furniture, "sofa", "couch", "easy chair" and "rocking chair" all rank in the top 10; they are closer to the prototype ("chair") due to the attribute overlap between these items. Attributes such as "you can sit on it" apply to all of them, but obviously do not apply to items such as "telephone", "fan" or "ashtray" in the same manner.

\subsection{Frames}

Research into prototypes and categorisation has partly led to Charles Fillmore's ideas on frames and frame semantics. Frames have their foundation in Fillmore's (1968) case grammar, which has since undergone a visible evolution. Apart from prototypes, Fillmore's early descriptions of frames were influenced by his own views on deixis, schemata and scenes (Fillmore 1976, 1977, 1982, 1987). He works early on with the concepts "buy" and "sell", and argues that these words call to mind very specific experiences and background knowledge, such as merchandise, transaction, money, buyer, seller, give, take, et cetera. This argument is echoed by Barsalou (1992: 35): "[...] buy cannot be understood fully without considering buyer, seller, merchandise and payment." Therefore, lexical items represent experience and encyclopaedic knowledge together with linguistic meaning.

Fillmore (2007: 238) defines frames as:

a system of concepts related in such a way that to understand any of them you have to understand the whole structure in which it fits [...]; words represent categorizations of experience, and each of these categories is underlain by a motivating situation occurring against a background of knowledge and experience.

Frames function similarly to Gestalt: the whole is sometimes more important than its parts. Fillmore (1982: 60) argues that when we know what the whole looks like, we will understand the vocabulary connected to that whole. We understand words (and concepts) like loan, deposit, instalment, payoff amount and interest on the basis of frames such as "commercial transactions" and "buy a car". We know that in most parts of the world, people generally have to apply to a bank for a loan when they want to buy a car. The buyer pays back the money through monthly instalments. The bank might require a potential buyer to put down a percentage of his/her own money as a deposit before they will consider approving the loan. The down payment is often connected to interest. In other words, a word such as "instalment" calls a much bigger frame to mind than the basic meaning of systematically paying back the borrowed amount. We understand the word on the basis of the different role players involved and the circumstances under which instalments are calculated and paid back. We know that instalments can only be paid back once a loan has been approved. Specific criteria are connected to the approval of a loan. The instalment frame also implies that a contractual agreement exists between the 
different parties (the buyer, the seller, and the bank), which determines the manner in which the loan has to be paid back. This frame includes aspects such as 'reputation'. Someone who pays back the loan diligently builds a positive credit record. Someone who fails to pay back the loan within the stipulated period might not get another loan in future.

In the same vein as Gouws (1991), Fillmore (2007: 243) additionally characterises frames as follows: "we can say that the frame structures the word-meanings, and that the word 'evokes' the frame." The speaker applies a certain frame to a specific situation by using words that are fixed within the given frame (Fillmore 2007: 246). In other words, the concept is lexicalised. Context is essential. A word cannot bring a frame to the fore without the relevant context. Fillmore (2007: 246) refers to the word "vegetarian". A vegetarian chooses to not eat meat. The choice to become a vegetarian is often related to a person's beliefs regarding animal rights, a person's health (or both) or religion. However, a person who only eats plant-based products because meat is either too expensive or unavailable in his/her immediate surroundings does not qualify as a vegetarian. Under certain circumstances, the word calls a specific frame to mind, which means that it will be inadequate under other circumstances. Thus, the word represents a category, "someone who does not eat meat", which can be used in different contexts and where the meaning can stand on its own. The word "vegetarian" cannot be fully understood and defined without knowing and considering the relevant categories. ${ }^{2}$

Differences in word sense can lead to differences in frames (Fillmore 2007: 249). Different kinds of texts and different kinds of languages can lead to different kinds of frames (Fillmore 2007: 255). Moreover, frames can be very big and may contain a large number of categories and sub-frames; frames can simultaneously contain a variety of meanings (Fillmore 2007: 248-249).

A frame structure that may be useful in determining the (ordinary) meaning of words is that of Barsalou. Having studied different frame structures, I have found Barsalou's methodology to be more accessible and better suited for legal purposes, with reference to ordinary words. Not only does it allow for a systematic approach to the interpretation of meaning, but it also includes the use of frame diagrams, which help users to visualise categories and concepts within a relevant frame as well as the underlying relations between them. Additionally, Barsalou's (1992) methodology uses a limited metalanguage. His approach to frames is examined in the next section.

\section{Barsalou's (1992) frame structure}

Barsalou (1992: 21) argues that frames are a useful instrument to generate specific concepts within a field. He sees frames as dynamic relational structures that have flexible and context-

\footnotetext{
2 "Someone who does not eat meat" can be seen as an ad hoc category. Barsalou (1983) argues that people create ad hoc categories to reach certain goals or to complete specific tasks. These categories differ from natural or general categories such as "fruit" or "murder". The concept of murder suggests that Person A killed Person B with premeditated intentions. Although ad hoc categories are focused on specific goals, a category in itself is random, for example, "things you need to take with you when you go camping next to the road". Barsalou (1983: 213-214) explains that ad hoc categories do not fully establish representation in memory, which means that general categories, like "murder", contain a number of members or items that are already present in a speaker's memory. For example, murderer, murder weapon, crime scene, murder investigation and murder victim are all fixed members within the "murder" category. Items that one might need for "things you need to take with you when you go camping next to the road" will probably be more random and differ from person to person.
} 
dependent forms. In addition, frames can be used to represent a number of things, such as exemplars, prototypes, membership and taxonomies (Barsalou 1992: 21). For this reason, I propose that jurists consider using frames to determine the ordinary meaning of words. This approach allows one to move beyond the contested word and its restricted dictionary definition and to tap into the conceptual network to which it belongs. Barsalou's (1992) frames consist of three components; namely attribute-value sets, structural invariants and constraints. Exemplars typically form attribute-value sets, with some characteristics (values) being instances of other characteristics (attributes). So, for example, "blue" and "green" are instances of "colour" (Barsalou 1992: 25). According to Barsalou (1992: 27), people learn, encode and remember information by taking note of the relations between concepts and their co-occurring data. This means that people usually know that the colours black and white regularly co-occur and that they correlate with the concepts "colour", "race", "printing", et cetera. By studying the cooccurring and correlated relations between an exemplar's attributes and values, a jurist may infer a lot about the meaning of a word under scrutiny.

Before I describe the three components of Barsalou's (1992) frames, I need to point out that this theory is much more complex than my present application. My approach to Barsalou's (1992) frames is simplified and nowhere do I claim that my basic approach is better or uncluttered. The reason why I have chosen to simplify this approach is purely to explore the possibility of constructing an accessible instrument for determining the ordinary meaning of words. It is important that linguists and non-linguists alike find frames a practical and user-friendly instrument.

\subsection{Attributes and values}

A co-occurring set of attributes constitutes the core of a frame (Barsalou 1992: 30). See Barsalou's (1992: 30) partial (and simplified) frame for "car" in Figure 1. ${ }^{3}$ Attributes of "car" are "driver", "fuel", "engine", "transmission" and "wheels". As a frame represents different exemplars, its attributes adopt different values. When the frame for "car" is applied to a specific exemplar (a Volkswagen Beetle, for example), its attributes might adopt values of "Phil" for "driver", "petrol" for "fuel", "two-cylinder" for "engine", "automatic" for "transmission" and "alloy" for "wheels". When applied to another exemplar, the same attributes might assume different values. Barsalou (1992: 30) sees an attribute as a concept that describes an aspect of at least some category members. "Wheels", "transmission" and "engine", for example, describe some of the aspects of "car", just as "passenger", "bonnet" and "spark plug" do. A concept takes the form of an attribute only when it describes an aspect of the frame as whole, that is, only when it indicates some characteristic of a category's members. However, the moment people consider "wheels" in isolation, it is no longer an attribute, but just a concept.

\footnotetext{
${ }^{3}$ I used the free and open source software application, Freeplane, to draw frames.
} 


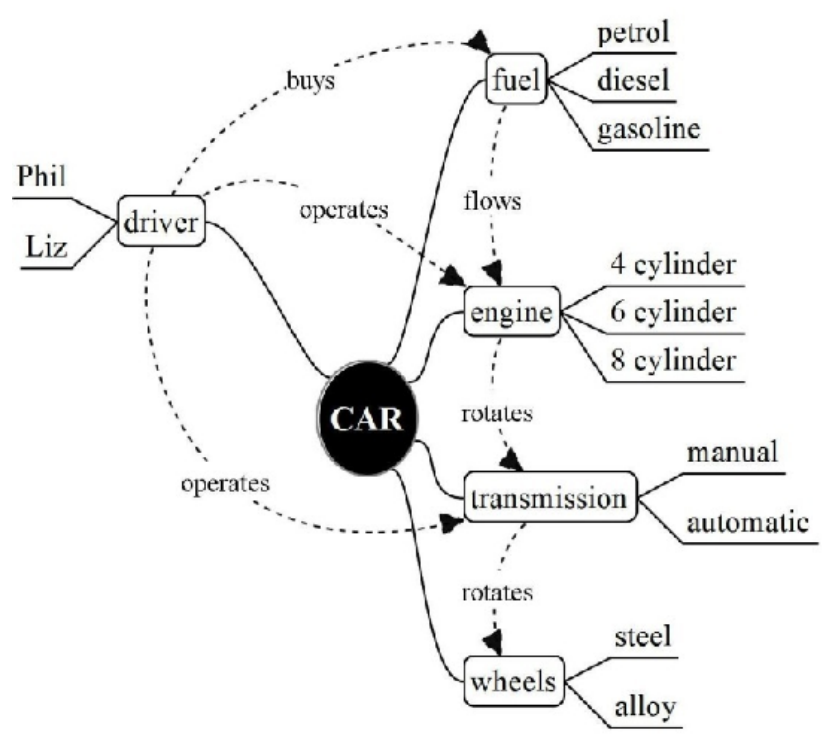

Figure 1: Barsalou's (1992: 30) partial frame for "car"

Attributes can represent a number of features of category members. They can include evaluations, quantities, costs, benefits, and so forth. They are likely to represent aspects such as colour, weight and shape, or location, time and goal. Barsalou (1992: 31) argues that a category's ontological domain will determine the aspects that qualify as attributes and that people regularly produce new attributes that are applicable to a specific context. People produce new attributes as they need them and those new attributes are then stored in memory and retrieved later in similar contexts (Barsalou 1992: 34). It is also possible for people to construct frames by adding an endless number of attributes and subsequent values, but the context and the user's needs will determine the features that are necessary. Moreover, frames can be split into smaller, related frames, because each attribute is a concept on its own.

Values represent types. Since values follow on attributes, they are subordinate concepts of an attribute, and because they are subordinate, they inherit information from their respective attribute concepts (Barsalou 1992: 31). "Two-cylinder", "three-cylinder" and "four-cylinder" are all values of "engine" (i.e., they represent types of engines). Because values inherit their information from attributes, they automatically become aspects of the category member. For example, "engine" is an aspect of "car" and so, too, is "two-cylinder". Values hold extra information that is not found in their attributes; i.e., they are more specific than attributes (Barsalou 1992: 31).

\subsection{Structural invariants and constraints}

Attributes should not be seen as independent units; they are conceptually dependent. Attributes reflect correlating relations that communicate conceptual information (Barsalou 1992: 35). Because attributes are conceptually dependent, some of the relations stay constant across contexts. Barsalou (1992) calls these constant relations structural invariants. In Figure 1, structural invariants are expressed between the driver and the fuel (buys), the driver and the engine (operates) and the driver and the transmission (operates), for example. Structural invariants describe relatively constant relations between a frame's attributes. The driver of a car has to buy fuel in order for the vehicle to propel itself forward. This relation is true for most 
exemplars. Even if the driver was steering a horse cart, he/she would still need to feed the horse at some point.

We can infer different things from these unchanging relations. First of all, the frame for "car" is not simply about a vehicle and its parts; it captures a wide variety of relational concepts, such as spatial, temporal, causal and intentional relations, to name but a few obvious ones (Barsalou 1992: 37). Consider the intentional relation for a moment: Phil buys fuel in order to operate the engine and transmission so that he can get the wheels of the car moving. He does all of this to go to work and to earn a pay cheque. Phil does not fill his car with fuel because he enjoys doing it. The car has to transport him from point A to point B. If we add speed limits and duration, we can start to explore temporal relations. It takes Phil 20 minutes to drive to work if he keeps to the speed limit of $60 \mathrm{~km}$ per hour; he takes 40 minutes if the roads are congested. It should be clear by now that frames contain a lot more information about concepts than a dictionary definition can possibly express.

Constraints are also relations, but of a different kind (Barsalou 1992: 37). Values are not independent of one another like attributes are. This leads to the possibility of values constraining one another in sometimes powerful and complex ways. In Figure 1, the value of the driver, Phil, may constrain attributes such as fuel, engine and transmission. If Phil does not have a driver's licence, he will not be legally permitted to drive the car (i.e. operate the engine and transmission). If Phil does not have any money, he will not be able to buy fuel in order to operate the car. However, if Phil drives the car without the necessary documentation and amount of fuel, he risks being arrested or stranded next to the road with an empty tank. Depending on the context, any of the values may place constraints on the rest of the frame. If Phil buys diesel for a petrol engine, he will be unable to travel very far; if the engine dies and Phil does not know how to fix it, he will not make any progress; and if Phil drives along and suddenly gets a flat tyre, his journey will be constrained by the wheels of the car, especially if the values of wheels are air and nitrogen, for example.

To summarise: attributes are concepts that describe aspects of category members; values are subordinate concepts that indicate type; structural invariants describe the fixed relations between attributes within a frame; and constraints are secondary relations that affect values and attributes and that may ultimately influence a frame as a whole.

\subsection{Application}

In order to test whether Barsalou's (1992) frame structure might be a viable instrument by which jurists can give certain words their ordinary meaning, I will apply it to two words taken from South African court cases. I will briefly relate the case information for clarity and follow with a discussion and conclusion of each word's possible ordinary meaning.

I also propose using the following six steps:

- Step one: study the context of the contested word

- Step two: identify the concept's attributes

- Step three: identify the concept's values

- Step four: determine the structural invariants

- Step five: determine the constraints 
- Step six: describe what the word means

Following Barsalou's (1992) example, I will indicate steps two, three and four on a semantic diagram. A visual representation of the frame will assist in showing how the attribute-value sets and conceptual relations are interconnected.

Because frames reflect both linguistic and encyclopaedic knowledge, users may use a variety of sources to build a frame. Dictionaries, thesauruses, encyclopaedias, text books, users' own intuition, and so forth, are all useful resources that users may want to consider when constructing their frame. It is important to note that frames may differ from one person to the next, because people often think differently. It is only natural that some people will identify particular attributes that other people might regard as less important. People who have personal experience with certain issues will have a completely different concept than people who have limited experience with the same issues. Rosch, Mervis, Gray, Johnson and Boyes-Braem (1976: 430) point out that experts in a specific domain of knowledge may list attributes for a concept that are ignored by the average person. They asked subjects to list attributes for the concept "airplane". One of the participants used to be an airplane mechanic. Not only did he list a greater variety of attributes, it also became clear that he viewed an airplane from a different angle; namely from the underside and the engine, instead of the top and the sides like the rest of the participants.

The two words used to illustrate Barsalou's (1992) frame were scrutinised for, among others, their "ordinary meaning" within their respective court cases. The first word, "plant", was dealt with by a full bench of the appellate division, whereas the second word, "vermin", was referred to a higher court for revision. These words were chosen randomly for the application.

\subsubsection{Blue Circle Cement Ltd v Commissioner for Inland Revenue: "Plant"}

Blue Circle Cement Ltd, a cement manufacturer, was dependent on limestone for the production of its product. The limestone was mined at a quarry situated $41 \mathrm{~km}$ from the manufacturing plant. The company determined that the most effective way to transport the limestone would be by rail. As a result, Blue Circle Cement built a train track between the quarry and the manufacturing plant. The limestone was excavated and broken into smaller pieces at the quarry before it was loaded onto a train and transported to the factory.

In terms of section 12(B)(1) of the Income Tax Act, companies are allowed to claim certain deductions for expenditure on equipment, among others. Blue Circle Cement made use of this opportunity and claimed deductions for expenditure relating to its railway line. The Commissioner denied the deductions, stating that the train tracks did not form part of the manufacturing plant and consequently did not form part of the cement factory's main operations. The cement manufacturer asked the court to determine whether the word "plant" could also include aspects such as machinery, apparatus and fixed structures.

A "plant" is a structural setup where raw materials are processed into useful products. Such a setup comprises a number of things, which can be represented by the following attributes: people, assets, transportation, factory and, ultimately, income. Refer to Figure 2. 


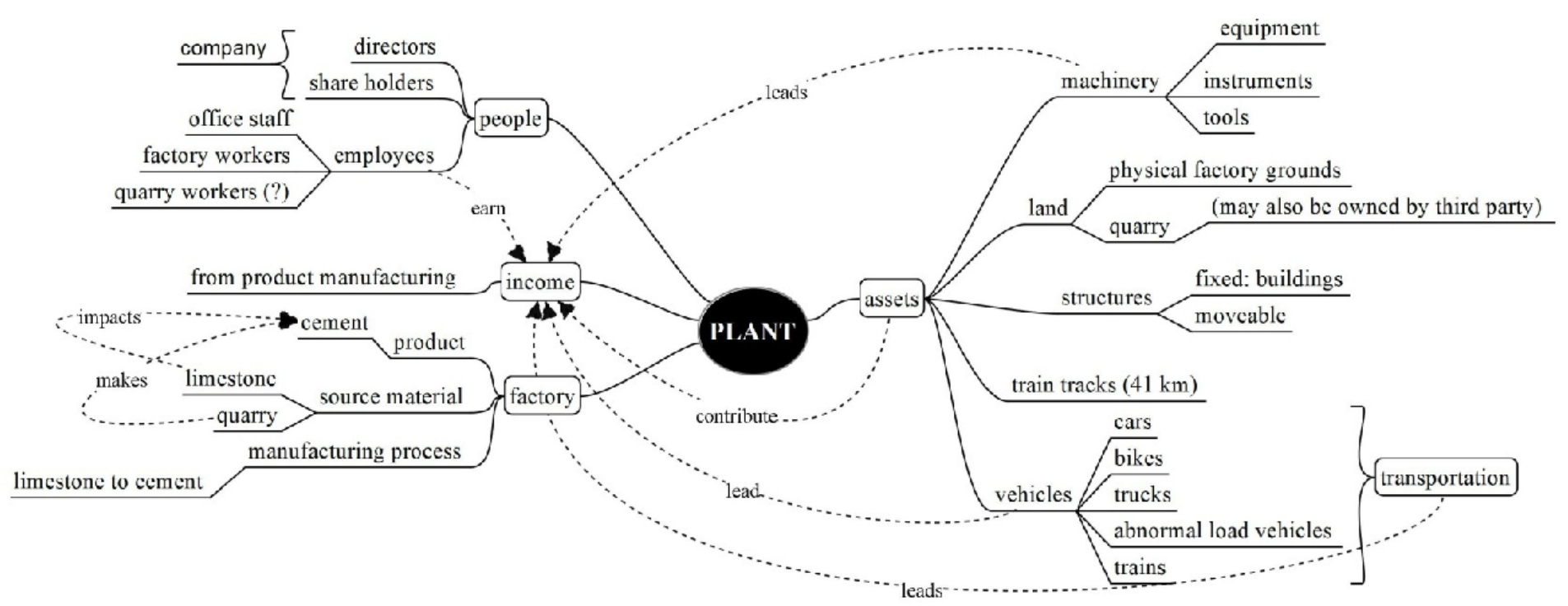

Figure 2: "Plant"

A company that owns a plant consists of a number of role players represented by values such as directors, shareholders and employees. These role players can be permanent or temporary. A plant is made up of different assets, which include machinery, land, structures and vehicles, and may contain things like train tracks. Some of the assets are fixed and some are moveable. That which the company does not own or do itself, it hires.

When most people think of a manufacturing plant, they probably picture a factory comprising buildings, chimneys and conveyor belts. However, a plant includes different types of fixtures (and moveable objects), which may occupy adjoining pieces of land. A plant is made up of the objects that it needs to process and manufacture materials. In the case of Blue Circle Cement, the $41 \mathrm{~km}$ train track formed part of the premises of the plant.

An attribute such as "assets" is cardinal to the core purpose of a plant. Without machinery, Blue Circle Cement could not process limestone and other ingredients into cement and without vehicles, the source materials could not make their way to the factory. Since limestone is a key ingredient in the making of cement, limestone had to be transported to the factory from wherever it was excavated. Only then could cement production take place. Transportation was necessary for the working of the cement plant; it was also necessary for delivering the final product to customers.

The attribute "factory" is just as important, because it is ultimately the factory where the product takes shape. In the case of Blue Circle Cement, the limestone would be useless without the factory. Most of the operations revolved around the factory and its main task - cement production. As can be seen in Figure 2, the factory needed a variety of resources, limestone being the most important one. Without this key ingredient, the factory's main task was impossible. Consequently, the excavation and transportation of limestone was just as important as the processing of the materials.

The last attribute is "income". Financial income and profit is the ultimate goal of a company. That is why Blue Circle Cement bought and developed the property, built the factory, employed people and bought assets. The company did all of this in order to generate an income. 
Connecting the quarry to the factory with a railway line was one of many things that Blue Circle Cement did to make money - and one of the parties who benefited directly from this income was the revenue service.

Therefore attributes like "assets", "transport" and "factory" have a direct influence on the "income" of "people" and the taxes they have to pay. It is here that structural invariants and constraints play a role. With reference to Blue Circle Cement, both the quarry and the transport between the quarry and the factory constrained the production of cement. If the limestone was not transported to the factory (either by truck or by train), then no cement could be produced. Moreover, production constrains income: no production, no income (and no taxes).

The word "plant" provides for both fixed and moveable installations such as a railway line. Blue Circle Cement's $41 \mathrm{~km}$ railway line was like an umbilical cord. It functioned as a direct line from the source to the manufacturing hub. Further, the fact that the quarry and the factory had a direct connection suggests that the train tracks and the train engines and wagons were part of the manufacturing plant. There should be no difference between the train engines and other vehicles servicing the plant, as there is no difference between the railway line and a conveyor belt as fixtures. In other words, just as a conveyor belt transports material from one end of a plant to another, the railway line aids in the transportation of limestone from the quarry to the factory. Also, Blue Circle Cement built the train tracks for private use; it was not a stateowned railway line used for both private and public purposes. The railway line now formed part of the property - part of the assets the company acquired. In other words, it formed part of the plant. If the company had decided to use a fleet of heavy-duty trucks (either its own or a contracted service) to transport the limestone to the factory, it might not have been in a position to claim the necessary deductions in terms of the Income Tax Act.

The fact that the word "plant" can include moveable and immovable objects is echoed in different dictionary definitions: the Oxford Historical Thesaurus (online) describes "plant" as "equipment for work" and the Oxford English Dictionary (online) defines "plant" in American English as "premises", "fittings", "equipment", "place where industrial process takes place" and "the workers of a factory". In Australian English, the word also has the meaning "stock and vehicles". Therefore, I conclude, that the ordinary meaning of the word "plant" can incorporate items such as a $41 \mathrm{~km}$ railway line.

The next word illustrates that a frame structure may also be used by non-linguists like zoologists, agriculturalists or any other party who may need to clarify the meaning of a particular word or term. Frames are not exclusive to linguists and law practitioners.

\subsubsection{S v Ntimbane: "Vermin"}

On 7 July 1988, Mr Ntimbane was seen killing a cane rat in the vicinity of the Tembe Elephant Park. He was subsequently arrested, because in terms of section 30(1)(a) of the KwaZulu Nature Conservation Act 8 of 1975 it was illegal to hunt wild animals within a nature reserve without the necessary permission. The magistrate who heard the case was unsure about the gravity of the crime and sent the case for review. In his report to the reviewing judge, the magistrate requested that the case be thrown out due to the fact that the respondent had been caught killing vermin and not a wild animal. 
The revised Act (9 of 1977) defines "wild animal" as:

any vertebrate animal (including a bird, a reptile but not a fish) whether bred or kept in captivity or elsewhere belonging to a non-domestic species whose habitat is either temporarily or permanently in any part of the Republic ... but does not include vermin ...

The word "vermin" is not defined in the Act, though the previous version of the Act (8 of 1975) lists hyenas, jackals, baboons, bush pigs and hyraxes (dassies) as examples of vermin. ${ }^{4}$ The fact that the revised Act does not define the word "vermin" makes it difficult to determine which creatures qualify as vermin, since hyenas, jackals and baboons all qualify as wild animals according to the definition cited above. Even if the legislator had provided a list of possible "vermin", parliament still does not explain what vermin is or when an animal qualifies as such.

What would the ordinary meaning of "vermin" be? In my opinion, "vermin" does not qualify as an ordinary word and should be treated as a zoological or agricultural term instead. Though I do not have a zoological or agricultural background, I dare argue that vermin status varies according to circumstances. "Vermin" as a concept may have the following attributes: creatures, feeding, reasons for population growth, habitat and status. See Figure 3.

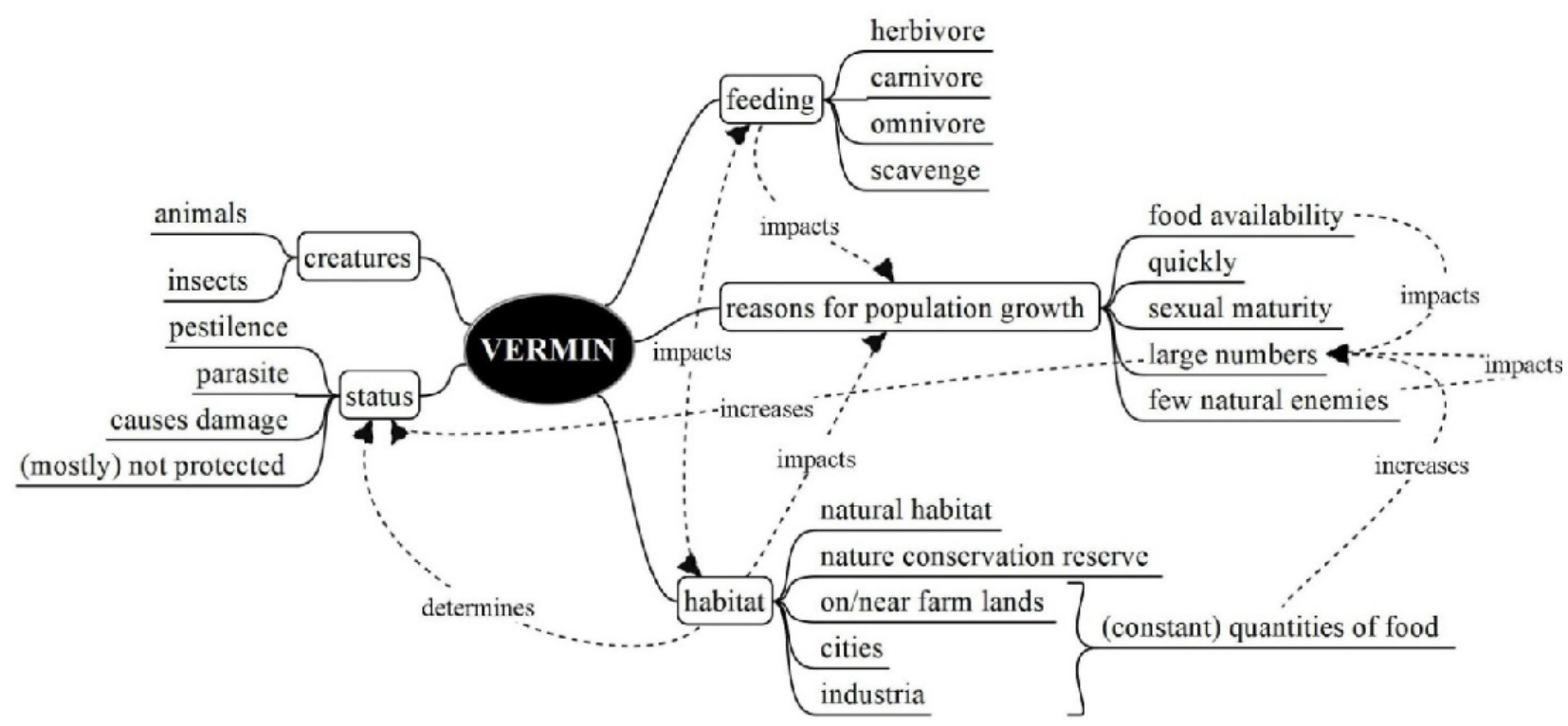

Figure 3: "Vermin"

The attributes "feeding", "reasons for population growth" and "habitat" correlate, and together they determine the vermin status of an animal. Therefore, any animal can be seen as vermin, depending on these attributes. Food is probably the most important factor; it determines where creatures live, has an influence on their population growth rate and will ultimately determine the level of destruction they cause to the environment, as well as the number of natural enemies they have. Food acts as a constraint: the more food there is, the more creatures there will be and

\footnotetext{
${ }^{4}$ To what extent some of these listed animals can still be considered vermin, is an important question. Animals like the lammergeyer, for instance, used to be severely persecuted and is now an endangered species. The same might be said for some species of jackal.
} 
the greater the destruction they cause to the environment, while the reverse is true when there is very little food to sustain large numbers. Natural enemies can also constrain a species. If there are very few enemies, the species may flourish. A combination of few or almost no enemies and plenty of food gives rise to a damaging situation. Cities and farms often provide certain animals with inexhaustible sources of food and many places to hide from danger. Rodents like rats can easily acquire the status of vermin in urban areas or farm lands due to few dangers and plenty of food. They earn the title of "pestilence" because they cause large-scale damage and their large numbers make them difficult to control. Moreover, they may lead to health risks and financial ruin if their numbers reach vast proportions. Therefore, it makes perfect sense that government does not want to protect animals known as vermin.

However, when there is a small population of species, they will obviously have a much smaller impact on their surroundings. This brings me to the cane rat. The cane rat is a large rodent that is found in sub-Saharan Africa. In South Africa you will find cane rats mostly in Gauteng and Mpumalanga areas, parts of KwaZulu-Natal and the Eastern Cape. A cane rat can weigh up to $7 \mathrm{~kg}$ and measure $60 \mathrm{~cm}$ in length (without its tail). Cane rats belong to the Tryonomys family and differ from their Rattus cousins. As herbivores they prefer marshy areas and mostly feed on aquatic grasses in their natural habitat. They also, of course, live in plantations where they tend to prosper. Cane rats found in large, destructive numbers on sugar cane plantations could be classified as vermin.

So, what does the word "vermin" mean? It might be safe to assume that vermin are creatures that tend to be destructive and difficult to control due to different factors like population size or evasiveness.

Now, the question is this: must a cane rat that lives in a small marsh be classified as vermin? A cane rat has to work that much harder to find food, few of its offspring will make it to adulthood due to lack of food and many dangers, and its impact on its environment is small enough to be absorbed by nature. Should a cane rat that lives in the vicinity of a nature reserve automatically be called vermin, because farmers a few kilometres down the road are experiencing destructive numbers on their plantations? Large elephant populations often cause major destruction in their environments, sometimes leading to forced culling, but does anyone ever refer to elephants as vermin?

Zoologists, agriculturalists and conservationists would admittedly be better able to argue this point (and may even prove the exact opposite of what I am saying). Even so, the way in which the legislator uses the word "vermin" is vague. Before the word can simply be applied to an animal, its context should be studied. Moreover, attributes such as "feeding", "habitat" and the animal's "population size" must be considered before a status can be assigned to that animal. The word "vermin" suffices as a good reason why jurists should be careful to depend on dictionary definitions only. By making use of frames, it should be clear that a word's meaning is conceptually interconnected to other aspects relevant to a contested word, as well as the context at hand.

\section{Conclusion}

More than 30 years ago, Van den Bergh (1981: 138) argued in favour of new approaches to the interpretation of statutes, especially where language is involved. Very little has since happened, 
leaving courts with the same need to reform. Alternative instruments for determining the meaning of words, such as corpus linguistic and conceptual approaches could be new, viable possibilities for South African law practitioners. As a matter of fact, a number of studies have already proven the usefulness of corpus linguistics in law, language and meaning and is therefore something worth considering.

Barsalou's (1992) frame structure has the benefit of providing for connotations, experience and meaning found in both colloquial and technical language use. Furthermore, it provides for word and meaning relations. One has a clearer image of meaning when one studies a semantic network. Barsalou's (1992) theoretical approach to frames can serve as a potential instrument for determining ordinary meaning and can either be used as an alternative to dictionaries or to complement them. In fact, many online dictionaries and thesauruses are now structured according to frame semantic principles. They often function thematically and provide readers with the many semantic relations connected to a specific word. Ultimately, this approach provides readers with a much clearer view.

By building a frame, a presiding officer and/or council can move beyond a dictionary definition to also justify aspects such as context and pragmatic language use for which traditional dictionaries often cannot account. This should be an approach that jurists could consider, especially when dictionaries (and preceding court cases) do not always provide the necessary clarity and certainty.

\section{References}

Barsalou, L.W. 1983. Ad hoc categories. Memory \& Cognition 11(3): 211-227.

Barsalou, L.W. 1992. Frames, concepts, and conceptual fields. In A. Lehrer and E.F. Kittay (Eds.) Frames, fields and contrasts. New essays in semantic and lexical organization. Hillsdale: Lawrence Erlbaum Associates. pp. 21-74.

Botha, C. 1998. Wetsuitleg: 'n inleiding vir studente. Pretoria: Juta and Co. Ltd.

Busse, D. 1989. Was is die Bedeutung eines Gesetzestextes? Sprachwissenschaftliche Argumente im Methodenstreit der juristischen Auslegungslehre - linguistisch gesehen. In F. Müller (Ed.) Untersuchungen zur Rechtslinguistik. Interdisziplinäre Studien zu praktischer Semantik und Strukturierender Rechtslehre in Grundfragen der juristischen Methodik. Berlin: Dunker und Humbolt. pp. 93-148.

Carney, T.R. and L. Bergh. 2014. 'n Taalkundige perspektief op woordeboekgebruik in die hof: die woordeboek as toevlugsoord. LitNet Akademies 11(2): 23-64.

Christensen, R. and C. Kübbeler. 2011. Wortlautgrenze und Wörterbuch. Zerl, 2/2011. Available online: www.zerl.uni-koeln.de/archive/zerl-2-2011/2954 (Accessed 30 March 2013).

Cockram, G.M. 1983. The interpretation of statutes. Cape Town: Juta and Co. Ltd.

De Ville, J.R. 2000. Constitutional and statutory interpretation. Cape Town: Interdoc Consultants (Pty) Ltd. 
Devenish, G.E. 1996. Interpretation of statutes. Johannesburg: Juta and Co. Ltd.

Dictionary unit for SAE. 2010. South African concise Oxford dictionary. Cape Town: Oxford University Press.

Du Plessis, L.M. 1986. The interpretation of statutes. Durban: Butterworths.

Du Plessis, L.M. 2002. Re-interpretation of statutes. Durban: Butterworths.

Fillmore, C.J. 1968. The case for case. In E. Bach and R.T. Harms (Eds.) Universals in linguistic theory. New York: Holt, Rinehart and Winston Inc. pp. 1-89.

Fillmore, C.J. 1976. Frame semantics and the nature of language. Annals of the New York Academy of Sciences 280(2): 20-32.

Fillmore, C.J. 1977. Scenes-and-frames semantics. In A. Zampolli (Ed.) Linguistic structures. New York: North-Holland Publishing Company. pp. 55-81.

Fillmore, C.J. 1982. Towards a descriptive framework for spatial deixis. In R.J. Jarvella and W. Klein (Eds.) Speech, place, and action. Studies in deixis and related topics. New York: John Wiley and Sons. pp. 31-59.

Fillmore, C.J. 1987. Schemata and prototypes. In R. Dirven and G. Radden (Eds.) Studies in descriptive linguistics. Fillmore's case grammar. A reader. Heidelberg: Julius Groos Verlag. pp. 99-105.

Fillmore, C.J. 2007. Frame semantics. In V. Evans, B.K. Bergen and J. Zinken (Eds.) The cognitive linguistics reader. London: Equinox. pp. 238-262.

Geeraerts, D. 2010. Theories of lexical semantics. Oxford: Oxford University Press.

Gouws, R.H. 1991. Leksikale semantiek. In T.J.R. Botha (Ed.) Inleiding tot die Afrikaanse taalkunde. Pretoria: Academica. pp. 382-411.

Hutton, C. 2009. Language, meaning and the law. Edinburgh: Edinburgh University Press.

Kellaway, E.A. 1995. Principles of legal interpretation: statutes, contracts and wills. Durban: Butterworths.

Kloosterhuis, H. 2007. Verhullend argumenteren met taalkundige argumenten. In E.T. Feteris, H. Kloosterhuis, H.J. Plug en J.A. Pontier (Eds.) Alles afwegende: Bijdragen aan het Vijfde Symposium Juridische Argumentatie, 22 juni 2007 te Rotterdam. Nijmegen: Ars Aequi Libri. pp. 261-268.

Labuschagne, J.M.T. 1988. Die woord as kommunikasiebasis in die wetgewingsproses. SuidAfrikaanse Publiekreg 3(1): 34-45. 
Labuschagne, J.M.T. 1998. Gewone betekenis van 'n woord, woordeboeke en die organiese aard van wetsuitleg. Suid-Afrikaanse Publiekreg 13(1): 145-148.

Langacker, R.W. 1987. Foundations of cognitive grammar. Vol. 1. Stanford: Stanford University Press.

Löbner, S. 2003. Semantik. Berlin: Walter de Gruyter GmbH.

Lyons, J. 1978. Semantics. Volumes 1 and 2. Cambridge: Cambridge University Press.

Mangasser-Wahl, M. 2000. Von der Prototypentheorie zur empirischen Semantik. Frankfurt am Main: Peter Lang GmbH.

Margolis, E. 2000. How to acquire a concept. In E. Margolis and S. Laurence (Eds.) Concepts: core readings. Cambridge, Mass.: MIT Press. pp. 549-568.

Oxford University Press. 2015. "Plant". Oxford English Dictionary. Available online: www.oed.com (Accessed 15 January 2015).

Oxford University Press. 2015. "Plant". Oxford Historical Thesaurus. Available online: www.oed.com (Accessed 15 January 2015).

Rey, G. 2000. Concepts and stereotypes. In E. Margolis and S. Laurence (Eds.) Concepts: Core readings. Cambridge, Mass.: MIT Press. pp. 279-299.

Rosch, E.H. 1973. Natural categories. Cognitive Psychology 4(3): 328-350.

Rosch, E. 1975. Universals and cultural specifics in human categorisation. In R.W. Brislin, S. Bochner and W.J. Lonner (Eds.) Cross-cultural perspectives on learning. New York: Sage Publications Inc. pp. 177-206.

Rosch, E. 2000. Principles of categorization. In E. Margolis and S. Laurence (Eds.) Concepts: core readings. Cambridge, Mass.: MIT Press. pp. 189-206.

Rosch, E. and C.B. Mervis. 1975. Family resemblances: studies in the internal structure of categories. Cognitive Psychology 7(4): 573-605.

Rosch, E., C.B. Mervis, W.D. Gray, D.M. Johnson and P. Boyes-Braem. 1976. Basic objects in natural categories. Cognitive Psychology 8(3): 382-439.

Smith, C.E. 2007. Enkele varianten van taalkundige interpretatie. In E.T. Feteris, H. Kloosterhuis, H.J. Plug en J.A. Pontier (Eds.) Alles afwegende: Bijdragen aan het Vijfde Symposium Juridische argumentatie, 22 juni 2007 te Rotterdam. Nijmegen: Ars Aequi Libri. pp. 249-256.

Smith, E. and D. Medin. 2000. The exemplar view. In E. Margolis and S. Laurence (Eds.) Concepts: core readings. Cambridge, Mass.: MIT Press. pp. 207-222.

Solan, L.M. 1993. When judges use the dictionary. American Speech 68(1): 50-57. 
Steyn, L.C. 1986. Die uitleg van wette. Johannesburg: Juta and Co. Ltd.

Taylor, J.R. 2009. Linguistic categorization. Oxford: Oxford University Press.

Taylor, J.R. 2011. Prototype theory. Available online: https://www.academia.edu/1902195/ Prototype_theory (Accessed 3 September 2014).

Van den Bergh, N.J.C. 1981. Die gebruikswaarde van bepaalde struktuuranalitiese metodes vir wetsuitleg. Tydskrif vir Suid-Afrikaanse Reg 2: 136-149.

Wittgenstein, L. 2000. Philosophical investigations, sections 65-78. In E. Margolis and S. Laurence (Eds.) Concepts: Core readings. Cambridge, Mass.: MIT Press. pp. 171-174.

\section{Cases}

Association of Amusement and Novelty Machine Operators v Minister of Justice 1980 (2) SA 636 (A).

Blue Circle Cement Ltd v Commissioner for Inland Revenue 1984 (2) SA 764 (A).

Commissioner for Revenue Service v Labat Africa Limited (669/10) [2011] ZASCA 157.

Herselman v Geleba (231/2009) [2011] ZAEQC 1.

Metro Transport (Pty) Ltd v National Transport Commission 1981 (3) SA 114 (W).

Sv Allied Steel (Pty) Ltd 1976 (4) SA 164 (R).

Sv Makunga and Others 1977 (1) SA 685 (AD).

Sv Mbatha 2012 (2) SACR 551 (KZP).

Sv Ntimbane $1990(2)$ SACR $302(\mathrm{~N})$.

Venter $v R 1907$ TS 1910.

\section{Acts}

Drugs and Drug Trafficking Act 140 of 1992.

Films and Publications Act 65 of 1996.

Interpretation Act 33 of 1957.

Income Tax Act 58 of 1962.

KwaZulu Nature Conservation Act 8 of 1975.

KwaZulu Nature Conservation Act 9 of 1977. 